References

1. Alexander F. Psikhosomaticheskaya medicina/ F. Alexander [per. s angl. A. M. Bokovikov, V. V. Starovoytov]. $-2018 .-382 \mathrm{~s}$.

2. Vasilenko T. D. Smyslovye aspekty telesnogo opyta chronicheskogo somaticheskogo zabolevaniia /T. D. Vasilenko, A. V. Selin, F. lu. Mangushev // Kurskii nauchno-practicheskiy vestnik "Chelovek i ego zdorovie". - 2016. - № 2. -S. 116-121.

3. Diabeticheskiy atlas [Electronny resurs] //Sposib dostupu: https://docplayer.ru/33391186-Mezhdunarodnaya-federaciya-diabetadiabeticheskiy-atlas.htm

4. Kachan E.P. Osobennosti vnutrennei kartiny bolezni u patsientov $s$ sakharnym diabetom 2-go tipa $v$ zavisimosti ot dlitelnosti zabolevaniia / E. P. Kachan, $\quad$ A. I. Kulak // Zhurnal Belorusskogo gosudarstvennogo universiteta. Filosofia. Psikhologia. - 2015. - S. 108-114.

5. Kyrylova O. O. Novyi pidkhid do vyvchennia lokusu kontroliu zdorovia v pidlitkiv iz tsukrovym diabetom I typu / O. O. Kyrylova // Ukrainskyi zhurnal dytiachoi endokrynologii. - 2017. - № 1. - S. 16-20.

6. Maslow A. Motivacia i lichnost / A. Maslow [per. s angl.]. - 1970. - $217 \mathrm{~s}$

7. Medzhydova K. O. Motivacia kak predmet nauchnych issledovanii // Psikhologia i Psikhotekhnika. - 2012. - № 4. - S. 44-50.

8. Mellina T. V. Psikhosomaticheskie aspekty razvitiya sakharnogo diabeta / D. N. Poberei // Ukrainskii naukovo-medychnyi molodizhnyi zhurnal. - 2012. - № 1. - S. 105-108.
9. Mendelevich V. D. Sakharnyi diabet / V. D. Mendelevich, S. L. Soloviova // Nevrozologia i psikhosomaticheskaya medicina - M. : MEDpress-inform, 2002 S. $561-568$

10. Nikonenko lu. P. Klinichna psykhologiya: navch. posib. / lu. P. Nikonenko. - K. : KNT, 2016. - $368 \mathrm{~s}$.

11. Pezeshkian N. Mne yasno kak spravitsya s diabetom/ N. Pezeshkian. - M. : DiaNovosti, 2003. - 223 s.

12. Prokopenko O. V. Povedinka spozhyvachiv: navch. pos./ O. V. Prokopenko, M. lu. Troayn. - K. : Centr uchbovoi literatury, 2008. - 176 s.

13. Shtrakhova A. V. Motivacionnyi component vnutrennei kartiny bolezni rfr factor priverzhennosti $k$ terapii $u$ bolnyh somaticheskimi zabolevaniyami s vitalnoi ugrozoi / A. V. Shtrakhova, E. V. Arslanbekova // Vestnik luUrGU. 2011. - № 29. - S. 82-89.

14. Faizullaev A. A. Motivacionnaya samoregulyacia lichnosti. Tashkent, 1987. - $136 \mathrm{~s}$.

15. Scherbyna L. F. Dynamika smyslovykh struktur osib, zaleznyh vid psyhoaktyvnyh rechovyn, $v$ procesi psyhologichnoi reabilitacii : avtoref. dys. kand. psyhol. nauk: spec. 19.00.04 "Medychna psyhologiya" / L. F. Scherbyna. - K., 2004. - 18 s.

16. Lustman P. J. Depression in diabetic patients: the relationship between mood and glycemic control/P. J. Lustman // J. of Diabetes Complications. - 2005. - Vol. 19. - P. 113-122

Надійшла до редколегії 18.06.19

Irina Burovska, post-graduate

Taras Shevchenko National University of Kyiv, Kyiv, Ukraine

\title{
DISABILITY OF MOTIVATION-SUMMER SPHERE IN PATIENTS WITH DIABETES MELLITUS
}

Psychological researches that reveal the essence of disorders of the motivational and semantic sphere in patients with diabetes mellitus are considered. Understanding the disease as a complex of somatic and psychological dysfunctions gives the opportunity to develop effective methods of support for chronically ill persons, to reveal the essence and to analyze the disorders of the motivational and semantic sphere in this group of persons. Particular attention is paid to the study of the aspect of intrinsic motivation, as extrinsic motivation is already present in the form of a disease with which one must learn to live. The stages of intrinsic motivation in patients with diabetes mellitus are examined in detail, the disorders that occur on each of them are identified and analyzed. The peculiarities of patients' motivational and semantic sphere as one of the most important personality substructures have been determined. The semantic sphere of personality and the basis of personal meaning (by $D$. $O$. Leontiev) are considered. The main directions of the study of diabetes as a psychosomatic disorder are described and analyzed, which makes it possible to search for harmonious adaptation of the patient in society and individual motives for leaving the disease. The analysis of the dynamics of the motivational - semantic sphere in patients with diabetes mellitus was carried out within the framework of scientific search of psychodynamic researchers, which gives an opportunity to understand the disease as a complex of somatic and psychological dysfunctions. Possibilities of positive psychotherapy and its role in the motivational and semantic sphere for patients with diabetes mellitus are considered. The focus of our view on psychological disorders is related to illness and the important role of physicality in blocking the semantic aspect in this category of patients. The prospects for further exploration and the need for comprehensive research in this problem area.

Keywords: motivational-semantic sphere, diabetes mellitus, disease, disorders, somatic disease.

Ирина Буровская , асп.

Киевский национальный университет имени Тараса Шевченко, Киев, Украина

\section{НАРУШЕНИЕ МОТИВАЦИОННО-СМЫСЛОВОЙ СФЕРЫ У БОЛЬНЫХ САХАРНЫМ ДИАБЕТОМ}

Рассмотрены психологические исследования, раскрывающие сущность нарушений мотивационно-смысловой сферы у больных сахарным диабетом. Описаны и проанализированы основные параметры возникновения и развития сахарного диабета. Определены особенности мотивационно-смысловой сферы у больных сахарным диабетом. Определены перспективы дальнейших исследований.

Ключевые слова: мотивационно-смысловая сфера, сахарный диабет, болезнь, нарушения, соматическое заболевание.

Bulletin of Taras Shevchenko National University of Kyiv. Series "Psychology". № 1(10), pp. 21-24 (2019)

УДК 159.9.92:364.636-053.6

DOI: https://doi.org/10.17721/BSP.2019.1(10).5
ISSN 1728-3817

(C) Taras Shevchenko National University of Kyiv,

Publishing Center "Kyiv University", 2019

Марина Величко, асп. Хмельницький національний університет, Хмельницький, Україна

\section{ПСИХОЛОГІЧНИЙ ЗМІСТ ТА ОСНОВНІ ПРИЧИНИ ВИНИКНЕННЯ МОБІНГУ СЕРЕД ДІТЕЙ СЕРЕДНЬОГО ШКІЛЬНОГО ВІКУ}

Метою статті є аналіз проблеми виникнення мобінгу серед дітей підліткового віку та встановлення сутності причини його виникнення у шкільному середовищі, основних характеристик поняття, а також пошуку шляхів запобігання мобінгу.

Ключові слова: мобінг, шкільне середовище, агресор, жертва.

Тема мобінгу серед дітей дедалі частіше опиняється в центрі уваги громадськості й наукових дискусій. Про насильство в школі та дитячих садках відомо давно. Починаючи із 1905 р., у пресі почали з'являтися перші роботи, присвячені цій проблемі, пік яких припав на кінець 1940-х рр. Сьогодні проблема шкільного насилля хвилює весь світ. Так, за даними Національної асоціації шкільних психологів США, щодня понад 160 тис. школярів пропускають заняття, побоюючись стати жертвою агресії [8].

Проблема мобінгу як педагогічна була окреслена ще у 1960-1980 рр. у Швеції, потім у Німеччині, Польщі та інших країнах Європи [3].
Термін "мобінг" $є$ доволі поширеним у літературних джерелах, особливо у зарубіжних виданнях, працях із соціології та психології. Це поняття ввів у 1963 р. К. Лоренц. Він називав мобінгом феномен групового нападу декількох дрібних тварин на більшого противника. Термін у сучасному розумінні вперше використав на початку 1980-х рр. учениймедик Г. Лейман. Він провів дослідження на робочих місцях у Швеції та оцінив кількість жертв мобінгу в країні$3,5 \%$ від усього населення й охарактеризував його як психологічний терор, що включає систематично повторюване й неетичне поводження однієї або декількох осіб, спрямоване проти іншої людини [4]. 
Мобінг (англ. to mob - нападати, гнобити, знущатися). Ситуація, коли в колективі одна або кілька осіб ставляться вороже до певної особи і здійснюють тиск на неї часто або упродовж тривалого часу (місяці, роки). Відрізняє його від інших конфрліктів те, що тут немає рівності сторін. У такому випадку сильніші переслідують слабшого з метою послаблення його позиції в групі або навіть витіснення з неї.

Психолого-педагогічні аспекти даної проблеми розглядалися у дослідженнях І. Філіппової, О. Матвійчук, Л. Гайнеман. Мобінг у шкільному колективі досліджували О. Корабльова, О. Юрчик, К. Дамбач, М. Шимановський, у робочих колективах - А. Задніпровська, Х. Лейманн. Мобінг як чинник, що загрожує життєдіяльності людини, вивчали Г. Гогіташвілі, В. Лапін. Соціально-психологічні аспекти мобінгу у військовому середовищі досліджували $€$. Потапчук, О. Адамчук. Однак поширеність явища, наявність протиріч між практичною потребою і станом вивчення проблеми обумовили актуальність дослідження даної проблеми.

Метою статті $\epsilon$ аналіз проблеми мобінгу серед підлітків та причини його виникнення у шкільному середовищі.

Шкільний мобінг - причина трагедій, що відбувається 3 його жертвами та одночасно причина негативного впливу на всіх учасників, оскільки він змінює особистість, травмує тих, хто брав участь у ньому, або ж виявився безсилим спостерігачем. До засобів знущання належать образи, поширення пліток, приниження, лихослів'я, бойкот, причіпки, кепкування, дезінформація, завдавання шкоди здоров'ю, дрібні крадіжки або псування особистих речей тощо. Зазвичай такі події відбуваються без свідків, а оточуючим нав'язується думка про те, що жертва сама створює проблеми або наприклад, що з її психічним здоров'ям не все гаразд. Мобінг $\epsilon$ цільовою дією стосовно усунення певної особи. Не всі дії учасників можуть бути свідомими.

У шкільному насиллі найчастіше бере участь група дітей. І якщо лідер угруповання - типовий мобер, тоді інші учасники таких угруповань - послідовники ініціаторів цькування однолітків [1]. За своєю сутністю, третирування - це специфічна форма агресивної поведінки, за якої сильніший (авторитетний) учень (або учні) систематично переслідує іншого (слабшого, аутсайдера). Ситуація третирування не обмежується лише ролями "агресора" і "жертви", вона "втягує" інших однокласників, роблячи їх активними або пасивними учасниками цих відносин. Шведський дослідник X. Лейман запропонував термін "моббінг" (або"психологічне тероризування"), під яким розумів ворожі неетичні комунікативні дії систематичного характеру, спрямовані на певного індивіда. Такі дії повторюються відносно часто (як мінімум один раз на тиждень) і тривають упродовж відносно довгого періоду (як мінімум півроку) [4].

Д. Ольвеус, відомий норвезький дослідник проблеми знущань у середовищі школярів, трактуючи означене поняття, наголошував на тому, що з дитини знущаються чи її переслідують, якщо вона неодноразово, протягом тривалого часу є об'єктом негативних дій з боку одного чи більше учнів. Із цього приводу О. Дроздов резюмує: "За своєю сутністю третирування - це форма насильницької поведінки у шкільному середовищі, за якої сильніший учень систематично переслідує слабшого (аутсайдера)". Д. Ольвеус у 1983 р. приділив увагу внутрішньородинним факторам, що провокують формування у дитини насильницьких рис особистості. На його думку, більший ризик піддатися насильству виявляється у дітей, які походять із таких сімей:

1. Неповні сім'ї. Дитина, яка виховується батькомодинаком, більше схильна до застосування емоційного насильства стосовно інших дітей. Причому дівчинка в такій сім'ї достовірно частіше застосовуватиме до інших емоційне насильство, ніж хлопчик.
2. Сім'ї, в яких у матері спостерігається негативне ставлення до життя. Матері, які не довіряють і негативно налаштовані щодо світу і школи, в котрій навчається дитина, зазвичай не бажають співпрацювати зі школою. У зв'язку із цим насильницькі дії, які виявляє у своїй поведінці дитина, матір'ю не засуджуються і не коригуються. У таких випадках матері схильні виправдовувати насильство як природну реакцію на спілкування з "ворогами".

3. Владні й авторитарні сім'ї. Виховання в умовах домінуючої гіперпротекції характеризується безумовним підпорядкуванням волі батьків, що впливає на те, що діти в таких сім'ях часто скуті, тому навчальний заклад може служити каналом, де вони виявляють свій внутрішньо пригнічуваний гнів і страх.

4. Сім'ї, які відрізняються конфліктними сімейними відносинами. У сім'ях, де дорослі часто сваряться та лаються, агресивно самостверджуючись у присутності дитини, працює так звана "модель навчання". Діти засвоюють і надалі застосовують ї̈ в повсякденному житті як прийнятний спосіб поведінки у конфоліктній ситуації. Таким чином, одна модель поведінки може передаватися з покоління в покоління як сімейна негативна установка. По своїй суті тривожна атмосфера сім'ї змушує дитину захищатися, вести себе агресивно. У таких сім'ях практично відсутня взаємна підтримка і близькі стосунки. Діти із сімей, в яких практикується насильство, оцінюють насильницькі ситуації інакше, ніж інші діти. Наприклад, дитина, що звикла до насильницької комунікації - наказового звернення до неї, незадоволеного та підвищеного тону у спілкуванні, оцінює його як нормальний. Тому в покрикуваннях і ляпасах, як з боку вчителя, так і з боку батьків, вона не буде бачити нічого поганого.

5. Сім'ї з генетичною схильністю до насильства. У дітей різна генетична основа толерантності (переживання) стресу. У дітей із низькою толерантністю до стресу виявляється велика схильність до насильницьких дій. Крім того, низька успішність також $є$ фактором ризику виявів насильства. Дослідження дають можливість стверджувати, що хороші оцінки із предметів позитивно корелюють із більш високою самооцінкою. Для хлопчиків успішність у школі не настільки значуща і меншою мірою впливає на самооцінку. Для них важливіше бути успішним у спорті, позашкільних заходах, походах та інших видах діяльності. Дівчатка, які мають низьку успішність із навчальних предметів, мають більший ризик вияву агресії стосовно однолітків, ніж хлопчики з поганою успішністю [2].

Найчастіше жертвами шкільного насилля стають учні, які мають: фізичні недоліки або вади; особливості поведінки; особливості зовнішності; страх перед школою; відсутність досвіду життя в колективі; хвороби епілепсія, заїкання, порушення мовлення, низький рівень інтелектуального розвитку і труднощі у навчанні.

У словнику С. Ожегова "насильство" визначається як застосування фізичної сили до кого-небудь, примусова дія на когось, утиск, беззаконня [5]. Беручи до уваги сказане, уважаємо, що шкільне насильство соціально-психологічне явище, для якого характерне використання будь-яких дій однієї людини щодо іншої (учень - учень, учитель-учень, учень-учитель) в умовах освітнього середовища, унаслідок яких завдається шкода фрізичному і/або психічному здоров'ю. При цьому слід ураховувати, що шкільне насильство:

- породжує невипадкові дії, а навмисні (проте кривдники приховують справжні свої наміри);

- характеризується порушенням особистих прав і свобод конкретної учня;

- унеможливлює самозахист індивіда через асиметрію сил (одна сторона завжди має переваги над іншою).

Серед причин насильницької поведінки виокремлюють такі чинники: зовнішні (соціальні); внутрішні (психологічні); біологічні. 
Зовнішніми чинниками, що негативно впливають на розвиток і поведінку дітей та підлітків, є такі:

Процеси, що відбуваються в суспільстві:

- екологічні й економічні кризи. Вони викликають у дітей відчуття безнадійності й роздратування. У підлітка розвивається протест, часто неусвідомлений, а разом із ним зростає рівень індивідуалізації, що в разі соціальної зацікавленості веде до егоїзму;

- темп і ритм технологічних перетворень. Швидкість зміни вимог суспільства, що стоять перед підростаючим поколінням, та їхня кількість;

- відсутність позитивних суспільних цінностей. Підліток, більш ніж інші вікові групи, страждає від нестабільної моральної обстановки у країні, втрачає орієнтацію в цінностях та ідеалах;

- недосконалість законів і роботи правоохоронних органів, беззаконність злочинів;

- відсутність соціальних гарантій та державної підтримки економічно неспроможних сімей із дітьми;

- руйнування та криза традиційних інститутів соціалізації підростаючого покоління (дитячих і юнацьких організацій, сім'ї та школи тощо);

- пропаганди насильства і жорстокості через засоби масової інформації, що глибинно впливає на формування особистості підлітка, у якого ще не сформована чітка життєва позиція;

- недоступність для учня безкоштовної якісної додаткової освіти (гуртків, секцій тощо), але доступність тютюну, алкоголю [6].

Ситуація в сім'ї:

- неповна сім'я; матеріальне становище сім'ї (як бідність, так і багатство);

- низький соціально-культурний рівень батьків, відсутність сімейних традицій;

- стиль виховання в сім'ї (відсутність єдиних вимог до дитини, жорстокість батьків, їхня безкарність і безправ'я дитини);

- заперечення самоцінності дитини;

- задоволення потреб дитини (нестача або надлишок);

- зловживання батьків алкоголем або наркотиками тощо;

- байдуже ставлення батьків до вживання дитиною психоактивних речовин.

Недоліки в організації шкільного життя:

- низький рівень інтелектуального, моральноетичного розвитку та навчальної мотивації школяра;

- навішування ярликів, приниження вчителем особистості учня;

- відсутність зв'язку школи із сім'єю учня, авторитарний або надмірно ліберальний стиль взаємовідносин у системі "учень - педагог".

Важливо враховувати, що однією із причин появи агресивної поведінки у дітей $є$ біологічні чинники ризику. Учень може мати органічні (посттравматичні, постінфекційні) або конституційні (вроджені, генетичні) ураження головного мозку, відповідно до яких розвивається акцентуація характеру за певним типом або психопатія. У даному випадку за умови несприятливого мікро- та макросередовища у дитини можливі вияви жорстокості та агресії.

Серед негативних зовнішніх, об'єктивних впливів на дитину діють внутрішні чинники ризику виникнення насильницької поведінки. Серед них науковці виокремлюють такі:

- психологічні особливості підліткового віку (криза підліткового віку);

- особистісні характеристики дитини-підлітка;

- міжособистісні взаємостосунки дітей [6].

Підлітковий вік - один із найбільш складних етапів розвитку людини. Незважаючи на відносно коротку три- валість (із 10 до 16 років), він багато у чому визначає подальше життя людини. Підлітковий вік називають складним, критичним або переломним, адже у цей період відбувається багаторівнева перебудова організму дитини, завершується фрормування особистості. Окрім того, відбуваються зміни у мотиваційній сфері - разом із навчальною мотивацією на перший план починає виступати потреба у спілкуванні з однолітками. Нестабільність емоційної сфери, егоцентризм, бажання долучитись до дорослого життя, належати до групи однолітків характерні для цього періоду. Агресія, що часто виникає у підлітків через слабкість самоконтролю і має здатність фріксуватися у свідомості як найбільш легкий шлях розв'язання складних ситуацій, часто має вияв у фізичній та вербальній агресії, образах, цькуванні (мобінгу) інших. Підліток використовує фрізичну силу проти інших, висловлює свої негативні почуття у формі погроз, ультиматумів, намагається виражати свою злість, спрямовану конкретно на когось, за допомогою інших людей (злі жарти, плітки, цькування) [6].

Серед особистісних характеристик підлітка виокремлюють:

- уразливість, що сприяє запам'ятовуванню неприємних подій, образ, страхів, переживань, із фріксацією на них;

- імпресивність - схильність до внутрішнього переживання почуттів і переживань, невміння ділитися ними з оточенням;

- внутрішня нестійкість, через чинники нервової конституції або поєднання полярних (холеричних і флегматичних) рис темпераменту батьків;

- емоційність, безпосередність у вираженні почуттів;

- невпевненість у собі

- підкреслене почуття власної гідності й беззахисність у спілкуванні з однолітками;

- існування протилежно спрямованих почуттів і переживань, наприклад, залишатись собою і в той же час бути разом із усіма:

- схильність до занепокоєння, хвилювання, тривожності;

- беззахисність, що виявляється у спілкуванні з однолітками, коли підліток не може захистити себе

- незнання або неприйняття соціальних норм і цінностей;

- невміння критично мислити і приймати адекватні рішення відповідно до різних ситуацій;

- невміння виражати власні почуття та реакції.

Наявність більшої кількості вищеперерахованих характеристик $є$ можливою причиною невдалої соціалізації дитини та виникнення мобінгу у спілкуванні та шкільному середовищі серед підлітків. Негативні наслідки мобінгу у спілкуванні $€$ такими: руйнування комунікативних умінь, побоювання та відсутність бажання спілкуватися з людьми. Коли поєднуються тривога, страх і втрата здатності до повноцінного спілкування, можливим стає виникнення страху спілкування із класом. У жертви мобінгу на основі дискомфорту, який вона відчуває у власному класі, зникає бажання відвідувати заняття. Реалізовуючи його, жертва пропускає навчальні заняття, або ж посилаючись на неіснуючі хвороби, припиняє відвідувати навчальний заклад. Тому важливою $є$ позиція класного керівника, спеціалістів соціально-психологічної служби та виховного відділу навчального закладу у роботі з дітьми, які часто пропускають навчальні заняття. Головною метою, за наявності таких фактів, $є$ виявлення та проведення психолого-педагогічної роботи із жертвою мобінгу та агресором, розроблення системи заходів із попередження мобінгу в учнівському середовищі.

Шкільне насильство завдає дитині тяжких травм, які мають згубні наслідки для її подальшого фрізичного та психічного здоров'я. По-перше, тривалі шкільні глузування 
позначаються на "Я-образі" дитини. Знижується самооцінка, учень почувається зацькованим. Жертва насильства може уникати стосунків з іншими людьми, або, навпаки, інші уникатимуть дружби з нею, оскільки бояться самі стати жертвами. Така дитина надалі може жити за сценарієм "невдахи". По-друге, роль жертви є причиною низького статусу в групі, проблем у навчанні та поведінці. У таких дітей високий ризик розвитку нервово-психічних і поведінкових розладів. Для жертв шкільного насильства характерні невротичні розлади, депресія, порушення сну й апетиту. По-третє, шкільне насильство викликає порушення в розвитку індивідуальності. Тривалий стрес породжує почуття безнадійності й безвихідності.

До наслідків мобінгу можна віднести неадекватне сприйняття власної індивідуальності - занижена самооцінка, комплекс неповноцінності, беззахисність; неадекватне сприйняття реальності - формування дезадаптаційних захисних психологічних механізмів; тривога, стрес, фобії, депресії, неврози, страх; відхилення в поведінці - адиктивна, антисоціальна (крайньої формою якої є кримінальна), суїцидальна поведінка; формування залежностей: алкогольна, тютюнова, наркотична, психологічна тощо; порушення в комунікативній сорері, страх спілкування 3 людьми, крайня недовіра до людей. Одним із ключових завдань педагогічних працівників у контексті вирішення даної проблеми є превенція агресивності та насилля в освітньому середовищі.

Отже, причини шкільного насильства серед підлітків надзвичайно складні й різноманітні, вони не є ізольованими одна від одної. Між ними існує зв'язок, як між соціальним і біологічним, успадкованим та набутим, фрізіологічним і психічним, індивідуальним та суспільним. Тому важливої уваги, на нашу думку, потребує соціально-педагогічна та корекційна робота з учасниками шкільного насилля. На першому місці у даній роботі має стояти створення психологічного комфорту для отримання жертвами мобінгу позитивного досвіду підтримки й довіри. По-друге, сфрормування навичок упевненої поведінки, розвиток упевненості в собі, позитивного самосприйняття. По-третє, допомога учням розвинути навички конструктивного спілкування, комунікативної компетентності. По-четверте, мінімізація відчуття дитиною своєї одинокості шляхом формування потреби у належності до групи та підвищення рівня емоційної комфортності шляхом зниження тривожності. Так, педагогам і психологам у своїй роботі з учнівським колективом, в якому зафіксоване явище мобінгу, варто зосередити увагу в напрямку зниження агресивності, формування толерантності, емпатійності в учнів з метою вторинної профрілактики виникнення шкільного насильства.

\section{Список використаних джерел}

1. Гогіташвілі Г.Г. Стрес і мобінг як причини травматизму / Г. Г. Гогіташвілі, В. М. Лапін // Безпека життєдіяльності. - 2005. - № 8. С. $14-17$

2. Дроздов О. Ю. Феномен третирування в школі: шляхи вирішенняпроблеми / О. Ю. Дроздов // Соціальна психологія. - 2007. - № 6. C. $124-128$.

3. Корабльова О.О. Вплив мобінгу на соціалізацію школяра / О. О. Корабльова // Зб. наук. пр. Хмельницьк. інституту соціальних технологій Університету "У"країна. - 2011. - № 3. - С. 79-83.

4. Leymann H. The Mobbing Encyclopaedia [Electronic resource]. Access mode: www.leymann.se/English/frame.html.

5. Ожегов С.И. Словарь русского языка: [ок. 57000 слов] / С. И. Ожегов, Н. Ю. Шведова. - 17-е изд., стереотип. - М. : Рус. яз., 1985.

6. Терещенко Л.А. Особливості прояву підліткової агресії/ Л. А. Терещенко // Практичний психолог: школа. - 2013. - № 10. - С. 38-45.

7. Юрчик О. М. Психологічні особливості дітей - жертв шкільного насильства / О.М.Юрчик // Актуальні проблеми психології особистості та міжособистісних взаємин, 24-25 квітня 2014 р. : Матеріали VI Міжнар. наук.-практ. конф. / за ред. С. Д. Максименка, Л. А. Онуфрієвої. - Кам'янець-Подільський, 2014. - С. 131-134.

8. Я навчу тебе не битися. Формування ненасильницької моделі поведінки учня // Шкільний світ. - 2014. - № 3(99). - С. 10-11.

\section{References}

1. Hohitashvili H. H. Stres i mobinh yak prychyny travmatyzmu / H. H. Hohitashvili, V. M. Lapin // Bezpeka zhyttiediialnosti. - 2005. - № 8. S. $14-17$.

2. Drozdov O. Yu. Fenomen tretyruvannia v shkoli: shliakhy vyrishennia problemy / O. Yu. Drozdov // Sotsialna psykholohiia. - 2007. - №6. S. $124-128$

3. Korablova O. O. Vplyv mobinhu na sotsializatsiiu shkoliara / O. O. Korablova // Zbirnyk naukovykh prats Khmelnytskoho instytutu sotsialnykh tekhnolohii Universytetu Ukraina. - 2011. - № 3. - S. 79-83.

4. Leymann H. The Mobbing Encyclopaedia [Electronic resource]. Access mode: www.leymann.se/English/frame.html.

5. Ozhehov S. Y. Slovar russkoho yazыka: [ok. 57000 slov] / S. Y. Ozhehov, N. Yu. Shvedova. - 17-e yzd., stereotyp. - M. : Rus. yaz., 1985.

6. Tereshchenko L. A. Osoblyvosti proiavu pidlitkovoi ahresii / L. A. Tereshchenko // Praktychnyi psykholoh: shkola. - 2013. - № 10. S. $38-45$

7. lurchyk O. M. Psykholohichni osoblyvosti ditei - zhertv shkilnoho nasylstva / O. M. Yurchyk // Aktualni problemy psykholohii osobystosti ta mizhosobystisnykh vzaiemyn, 24-25 kvitnia 2014 r. : Materialy VI Mizhnarodnoi naukovo-praktychnoi konferentsii / za red. S. D. Maksymenka, L. A. Onufriievoi. Kamianets-Podilskyi, 2014. - S. 131-134.

8. la navchu tebe ne bytysia. Formuvannia nenasylnytskoi modeli povedinky uchnia // Shkilnyi svit, 2014. - № 3(99). - S. 10-11.

Надійшла до редколегії 29.05.19

Marina Velichko, post-graduate

National University of Khmelnytsky, Khmelnytsky, Ukraine

\section{PSYCHOLOGICAL MEANING AND MAIN CAUSES OF MOBBING} AMONG CHILDREN OF SECONDARY SCHOOL AGE

The article is an analysis of the mobbing problem occurrence among children adolescents, establishing the causes of a school environment the main characteristics of the concept and finding ways to prevent mobbing.

The method of studying the problem of mobbing in children in the school environment explains to us the root causes of its occurrence, reveals the very essence of its appearance, as well as the manifestations of mobbing in middle school age children from their peers.In a deeper analysis of the problem of mobbing, we identified the main aspects of preventing this phenomenon, also developed a methodological plan for the prevention of mobbing in schools, and developed and described preventive measures to prevent manifestations among middle school children for teachers and parents who have and can influence students or their children in the context of this issue.

The findings of this paper reflect the state of the problem of mobbing in the current educational process in Ukraine, taking into account the actualization of its manifestations due to the large number of displaced persons, including middle-aged children, from temporarily occupied territories during the Russian armed aggression against our country. The processes taking place in our extremes and in the world are inevitable for society as a whole, and so the challenge we face requires more detailed consideration of the issue of mobbing among adolescents of schools, the urgent response to its present manifestations, and addressing these issues, specifics of personal approaches to middle school children in each case.

Analyzing the problem of mobbing among children in school, especially middle school children, we have come to the conclusion that the multiplicity of influence factors determines the direction of the study of the problem and gives this problem a new special approach, taking into account many points, and obliges us to solve the problem of mobbing the school, so that it does not persecute a person who is primarily a person, in adolescence and adulthood.

Keywords: mobbing, school environment, aggressor, victim.

Марина Величко, асп.

Хмельницкий национальный университет, Хмельницкий, Украина

\section{ПСИХОЛОГИЧЕСКОЕ СОДЕРЖАНИЕ И ОСНОВНЫЕ ПРИЧИНЫ ВОЗНИКНОВЕНИЯ МОББИНГА СРЕДИ ДЕТЕЙ СРЕДНЕГО ШКОЛЬНОГО ВОЗРАСТА}

Целью статьи является анализ проблемы возникновения моббинга среди детей подросткового возраста и установление сущности причин его возникновения в школьной среде, основных характеристик понятия, а также поиска путей предотвращения моббинга. Ключевые слова: мобинг, школьная среда, агрессор, жертва. 